\title{
Editorial
}

\section{Current mechanisms in stroke}

\author{
Hong-shuo SUN* \\ Departments of Surgery, Physiology, and Pharmacology; Institute of Medical Science, Faculty of Medicine, University of Toronto, \\ Toronto, Ontario, Canada M5S 1 A8
}

Acta Pharmacologica Sinica (2013) 34: 1-2; doi: 10.1038/aps.2012.174; published online 24 Dec 2012

Stroke is one of the leading causes of mortality and adult disability in the world ${ }^{[1-3]}$. The occurrence of stroke and strokerelated illness is expected to triple by $2050^{[4]}$, due to our vulnerable aging population and ongoing epidemics of diabetes and obesity ${ }^{[1,5]}$. Disabilities associated with stroke survivors have had a significant social and economic impact on societies worldwide ${ }^{[2]}$. According to the World Health Organization, about 15 million people worldwide suffer a stroke every year. Furthermore, stroke and its related illnesses cost the healthcare system billions of dollars each year, thus becoming significant financial burden and causing economic hardship in the world.

While stroke is a major public health concern, the cellular and molecular mechanisms underlying brain damage following stroke are not yet fully elucidated. A series of pathophysiological events are triggered during stroke, and eventually lead to intracellular ionic imbalance and cell death ${ }^{[6,7]}$. Glutamate mechanisms have dominated in stroke research for the last two to three decades ${ }^{[8]}$. Although glutamate receptor antagonists are effective in reducing stroke-related neuronal injury in the laboratory setting, clinical trials of anti-excitotoxic therapies have failed to benefit stroke patients ${ }^{[9]}$. Thus, researchers have started looking beyond glutamate mechanisms in cerebral ischemia and stroke. Recent convincing and promising results, especially from in vivo animal studies, suggest non-glutamate mechanisms are also important in causing ionic imbalance and cell death during cerebral ischemia ${ }^{[8,10]}$. Along with the traditional model of excitotoxicity focused on glutamate-receptor-mediated mechanisms, non-glutamate mechanisms are gaining considerable attention in recent years $^{[8,10]}$. The latter include acid-sensing ion channels ${ }^{[11,12]}$, TRP channels ${ }^{[13,14]}, \mathrm{K}_{\text {ATP }}$ channels ${ }^{[15,16]}$, hemichannels ${ }^{[17,18]}$, volume-regulated anion channels ${ }^{[19]}$, adenosine receptors, sodium-calcium exchangers, and other ion exchangers and

\footnotetext{
* To whom correspondence should be addressed.

E-mail hss.sun@utoronto.ca
}

nonselective cation channels.

In this special issue of stroke research, we aim to cover the revised models of neuronal injury involving glutamate mechanisms and several newly identified non-glutamate mechanisms in stroke. We will discuss the current understanding of pathophysiological roles of ion channels and exchangers involved in non-glutamate mechanisms in cerebral ischemia and stroke, as well as the potential for therapeutic intervention. We will describe new studies using recently developed experimental models for stroke research. The primary scope of our reviews is to highlight findings from in vivo studies involving new strategies and drug developments for stroke treatment. The in vivo experimental approaches cover state of the art techniques currently used in the fields including molecular, genomic, proteomic, in vivo functional and behavioural assessments. We intend to highlight novel therapeutic strategies targeting non-glutamate mechanisms to prevent neuronal damage in stroke and to promote neuronal survival, regeneration and functional recovery after stroke, thus providing long-term economic, social, and healthcare benefits worldwide.

\section{References}

1 Canadian Diabetes Association Website, http://www.diabetes.ca/ diabetes-and-you/living/complications/heart-disease-stroke/, 2005.

2 Stroke. http://www.strokeassociation.org/STROKEORG/AboutStroke/ About-Stroke_UCM_308529_SubHomePage.jsp, 2000.

3 Thom T, Haase N, Rosamond W, Howard VJ, Rumsfeld J, Manolio T, et al. Heart disease and stroke statistics--2006 update: a report from the American Heart Association Statistics Committee and Stroke Statistics Subcommittee. Circulation 2006; 113: e85-151.

4 Hebert LE, Scherr PA, Bienias JL, Bennett DA, Evans DA. Alzheimer disease in the US population: prevalence estimates using the 2000 census. Arch Neurol 2003; 60: 1119-22.

5 Yach D, Hawkes C, Gould CL, Hofman KJ. The global burden of chronic diseases: overcoming impediments to prevention and control. JAMA 2004; 291: 2616-22. 
6 Dirnagl U, ladecola C, Moskowitz MA. Pathobiology of ischaemic stroke: an integrated view. Trends Neurosci 1999; 22: 391-7.

7 Lipton P. Ischemic cell death in brain neurons. Physiol Rev 1999; 79: 1431-568.

8 Besancon E, Guo S, Lok J, Tymianski M, Lo EH. Beyond NMDA and AMPA glutamate receptors: emerging mechanisms for ionic imbalance and cell death in stroke. Trends Pharmacol Sci 2008; 29: 268-75.

9 Davis SM, Lees KR, Albers GW, Diener HC, Markabi S, Karlsson G, et al. Selfotel in acute ischemic stroke: possible neurotoxic effects of an NMDA antagonist. Stroke 2000; 31: 347-54.

10 Tymianski M. Emerging mechanisms of disrupted cellular signaling in brain ischemia. Nat Neurosci 2011; 14: 1369-73.

11 Pignataro G, Simon RP, Xiong ZG. Prolonged activation of ASIC1a and the time window for neuroprotection in cerebral ischaemia. Brain 2007; 130: 151-8.

12 Xiong ZG, Zhu XM, Chu XP, Minami M, Hey J, Wei WL, et al. Neuroprotection in ischemia: blocking calcium-permeable acid-sensing ion channels. Cell 2004; 118: 687-98.

13 Aarts M, lihara K, Wei WL, Xiong ZG, Arundine M, Cerwinski W, et al. A key role for TRPM7 channels in anoxic neuronal death. Cell 2003;
115: 863-77.

14 Sun HS, Jackson MF, Martin L, Jansen K, Teves L, Cui H, et al. Suppression of hippocampal TRPM7 protein prevents delayed neuronal death in brain ischemia. Nat Neurosci 2009; 12: 1300-7.

15 Sun HS, Feng ZP, Barber PA, Buchan AM, French RJ. Kir6.2-containing ATP-sensitive potassium channels protect cortical neurons from ischemic/anoxic injury in vitro and in vivo. Neuroscience 2007; 144: 1509-15.

16 Sun HS, Feng ZP, Miki T, Seino S, French RJ. Enhanced neuronal damage after ischemic insults in mice lacking Kir6.2-containing ATPsensitive $\mathrm{K}^{+}$channels, J. Neurophysiol 2006; 95: 2590-601.

17 Thompson RJ, Jackson MF, Olah ME, Rungta RL, Hines DJ, Beazely MA, et al. Activation of pannexin-1 hemichannels augments aberrant bursting in the hippocampus. Science 2008; 322: 1555-9.

18 Thompson RJ, Zhou N, MacVicar BA. Ischemia opens neuronal gap junction hemichannels. Science 2006; 312: 924-7.

19 Zhang Y, Zhang H, Feustel PJ, Kimelberg HK. DCPIB, a specific inhibitor of volume regulated anion channels (VRACs), reduces infarct size in MCAO and the release of glutamate in the ischemic cortical penumbra. Exp Neurol 2008; 210: 514-20. 